\title{
The effectiveness of audio media for english learning based on scripted song at the fifth grade of elementary school
}

\author{
Erisa Kurniati, Universitas Batanghari, erisa.kurniati@unbari.ac.id, ORCID: 0000-0003-4008-1119 \\ Muhammad Zaim, Universitas Negeri Padang, mzaim_unp@yahoo.com, ORCID: 0000-0002-6152-6650 \\ Jufrizal, Universitas Negeri Padang, juf_ely@yahoo.com, ORCID: 0000-0003-2186-1873 \\ Jufri, Universitas Negeri Padang, jufri_bgdkayo@yahoo.com, ORCID: 0000-0001-5715-7461
}

\begin{abstract}
This study aims at determining the effectiveness of audio media based on scripted song that was developed based on themes for the fifth-grade elementary school students. After validation by two experts on content and quality, the developed media was implemented in Public Elementary School 205 / IV Jambi, which involved 25 students. The study design used a pre-post treatment design. The results of the study proved that the audio media is effective in increasing the fifth grade students' English competence especially in listening and speaking It is shown by the average learning achievements of 6.69 that are categorized fair before the action to 8.32, which are categorized good after the action. Besides, the results of the questionnaire proved that all students (100\%) showed a positive perception of the use of audio media based on scripted song They became more motivated to learn because through song, the learning became fun, interesting, and the learning material became more easily understood.
\end{abstract}

Keywords: Audio Media, English Learning, Scripted Song, Elementary School

Received: 19.03.2020 Accepted: 21.08.2020 Published: 15.01.2021

\section{INTRODUCTION}

In curriculum 2013 in Indonesia, English learning is not given explicitly in the curriculum structure, but English subjects could be given as local content subjects, and until now, many schools are still oriented towards KTSP curriculum in terms of giving English lessons as much as 2 hours in a week (Dewantara, 2020). It cause English has been a local content subject at elementary schools which was introduced from grade four to grade six since 1994. According to Harmer (1983), early introduction to English is based on a pedagogical concept that the earlier a person is introduced to the target language, the faster and the better the mastery and acquisition of children of the language being learned.

English subjects as the local content at elementary schools is also referred to the Government Regulation No. 22 of 2006. The regulation is concerning content standards confirms that learning English at elementary schools aims to make students have the ability to: (1) Develop limited oral communication competencies to accompany action (language accompanying action) in the school context, and (2) Having an awareness of the nature and importance of English in increasing the nation's competitiveness in the global community. Based on these objectives, learning English at elementary school should emphasize into the listening and speaking aspects, without neglecting the aspects of vocabulary, grammar, pronunciation, and aspects of writing and reading. It can be said that the purpose of learning English at elementary schools is to achieve oral communication competence that integrates all components of language namely vocabulary, grammar, and pronunciation. Students' English competence is measured by learning outcomes. Learning outcomes are changes in behavior as learning outcomes that include cognitive, psychomotor and affective aspects. Meanwhile, Dimyati (2006) defines learning outcomes as a result of an interaction of learning and teaching. Thus, what is meant by learning outcomes in this article are the results of English learning of fifth-grade elementary school students for two learning sessions with Sports topics shown from their ability to answer questions related to the material taught. 
Brown (1994) states that there are five categories that teachers must pay attention to in designing successful English learning for children, namely (1) Intellectual Development, (2) Attention Span, (3) Sensory Input, (4) Affective Factors, and (5) Authentic, Meaningful Language. The intellectual development means that children up to age 11 be still in a phase of intellectual growth called Piaget's "concrete operation". Good exposure is necessary to score adequate English competency. The teacher as a facilitator or catalyst must have adequate abilities, both in word choice and usage, intonation, and body expression. Minimal skills and misstatement will lead to language failure, which is mastered by children. Krashen (2002) states that the teacher's words and sentences in the learning process in the classroom are the same as "caretaker speech". They have a very strong influence on the language acquisition process that occurs in children. The child will copy and repeat what the teacher or caretaker speech did. Speeches that come out of the mouth and body expressions of a teacher aimed at students are called "caretaker" speeches. The "caretaker" speech is a very good intake (source of language acquisition) because the process emphasizes more on natural forms of communication. Therefore, the language skills and communication mastered by the caretaker must be adequate. So, all learning material should be packaged concretely, and avoid abstract concepts. With this limitation, all forms of learning in the form of rules, explanations, and discussions of language that are abstract should be carried out very carefully and present the endeavored concretely.

From the attention span dimension, children's concentration depends on the packaging of learning by the teacher. They will not pay attention to the lesson if the material being taught is boring, meaningless, and too difficult. Sensory input regarding learning should involve all the senses of children, be it vision, hearing, taste, smell, and touch. It means, that the teacher should be attention to the affective factors beingt so that learning can make children have a happy and comfortable attitude in learning, and authentic meaningful language is intended so that the language taught is authentic and useful in life. Willing (in Chitravelu, Sithamparam, \& Tea, 2005; Ali\&Ece, 2019) emphasized that concrete-type children will enjoy learning strategies that use games, pictures, films, cassettes, videos, and others as learning media.

However, various facts indicate that there are still various obstacles in the field in implementing adequate learning. The results of a survey in some elementary school English teachers in Jambi proved that the English teachers did not have an adequate educational background. Teachers tend to implement learning by pronouncing vocabulary through drills and explaining English vocabulary through translation into the first language. Furthermore, the results of interviews with English teachers also show that they have never used innovative audio learning media (Scripted Songs) and only refer to books.

The problems above, especially in media problems, can be solved by using more innovative learning media so that the teacher can vary the learning that can bring joy in the learning process to students. Gagne \& Briggs (1974) explained that learning media is a tool that is physically used to convey the content of subject matter, which consists of books, modules, programmed text, tape recorders, cassettes, video cameras, video recorders, films, slides, photos, pictures., graphics, television, computers, and so on. Arsyad (2011) further explains that if the media carries messages or information that are instructional or contain teaching purposes, then the media is called learning media. Therefore, it can be concluded that learning media are physical tools used in conveying information, namely in the form of learning materials to students. Furthermore, based on the technology used, the learning media are grouped into four; (1) media produced by printed technology, (2) media produced by audiovisual technology, (3) media produced by computer technology and, (4) media resulting from a combination of print technology and computer. Each of these learning media has different functions according to learning needs. Here, teacher must be able to determine the right learning media so that students can understand the material presented. Good learning media are media that can help the process of transferring subject matter well, attracting the attention of students, creating a pleasant learning atmosphere, and can motivate them (Arsyad 2011). It cause the learning process can become more dynamic and will achieve the desired goals if added tools or media, such as audio-visual media, print, projectors, films, games, and so on. Yassaei (2012) added that one of the most well-known ways to create meaningful contexts for 
learning English is through the use of media, which can be displayed through various formats, such as print, audio, and visual. While Hamalik (in Arsyad, 2011), argues that the use of instructional media in the teaching and learning process can arouse new desires and interests, generate motivation and stimulation of learning activities, and even bring psychological influence on students. In line with Hamalik's opinion, Shin (2006) and Mona et all (2020) also revealed that one way to increase students' attention and involvement in learning activities required supporting tools in the form of visual aids, toys, dolls or other colorful objects, which are appropriate with stories or songs used in learning, so that language learning becomes easier to understand.

In Indonesia, the research of media implementation for learning English at elementary school's students has been carried out. Each of these studies applies a different type of media but it has a good effect on the learning process of English in the classroom so that it can improve student's learning outcomes. Widodo \& Raharjo (2012) found that student learning activities in English language learning with the help of domestic animal flashcards media were significantly higher than the control group, as evidenced by the average activity of the experimental group of 88.25 while the activity in the control group amounted to 84.86 and tested using the independent $t$-test obtained $p$-value $=0.024<0.05$. It is knowing that learning English with flashcards was effective in improving learning outcomes and making students active.

Next, the research conducted by Bayu \& Wahyuni. (2019) This research is based on the low learning outcomes of learning English at elementary schools, especially after the implementation of the 2013 curriculum, where the time for learning English is much reduced from 4 hours a week in the Education Unit Level Curriculum (KTSP) to only 2 lessons a week in the 2013 curriculum. Based on the results it is known that the Enjoyable Learning strategy assisted by audio-visual media has a significant effect on English learning outcomes in grade II elementary school students in the implementation of the 2013 curriculum. Then there is also research on the use of multimedia learning products for English for grade IV SD conducted by Dwihartanti \& Gafur. (2015). This study produces multimedia products for learning English that is valid and effective as a learning medium.

In the curriculum 2013, the goal of learning English at elementary schools is to achieve oral communication competence (speaking and listening) that integrates all language components, namely vocabulary, grammar, and pronunciation. Students' English competence is measured through the achievement of learning outcomes. It means that the listening and speaking aspects should be emphasized without neglecting the aspects of vocabulary, grammar, pronunciation, and aspects of writing and reading. Moreover, the role of media in English learning at elementary can influence the students' motivation, create the fun and enjoy situation. Based on the things that have been explained above, it can be concluded that learning media is one of the important factors that can make the learning process successful. Media that is packaged attractively can motivate students to want and maintain learning, facilitate the learning process, make learning effective and efficient, and then improve learning outcomes. In this case, the scripted songs recorded in a cassette or CD that used in this study can be grouped into audio learning media. It is learning aids that are heard by students to get information in the form of English learning materials according to the theme taught. In the learning process, the teacher uses a tool in the form of a CD player or computer to present the material.

Thus, the teacher's job is to make learning more interesting, lively and fun. One of them is through the use of audio learning media (cassettes or CDs). In addition to being able to bring audio media fun, relaxed atmosphere, the most important thing is to be able to provide examples of language exposure that are rich in linguistic aspects, such as vocabulary, grammar, pronunciation, but also language skills (listening, speaking, reading, and writing). What's more, for teachers with non-English language education backgrounds, they can be helped with accurate language models in terms of pronunciation and intonation by repeating the available audio media. Therefore, in research (Ratminingsih \& Budasi, 2014) an audio learning media was developed, namely learning CDs based on creative songs based on themes in the fifth grade of elementary schools. 
According to Schoepp (2001), the song becomes an integral part of human language experience. Flattum (2008) adds that a song is a combination of melody and lyrics with harmony, rhythm or beets. Songs usually have a structure in the form of repetitions of poetry and chorus. The creation songs intended in this study are songs whose lyrics were created by researchers based on themes, while the melody is taken from the rhythm of music from Indonesian or foreign children's songs that are well known. Furthermore, Shtakser (2012) explains that music and songs can create a good learning atmosphere in the classroom. Brewster, Ellis, \& Girard (1992) also added that song is an ideal strategy for learning languages because in songs there are repetitions of vocabulary and language structure and rhythm that can increase student interest in learning. Besides, Malley stated two main benefits of using music and songs in language learning, namely songs are easily memorized and are very motivating for students (in Murphey, 1992). Murphey added that old music and songs are stored in the memory, and can be part of us and easily utilized in the classroom.

There are six advantages of using songs and music in language classes (Griffee, 1992) namely (1) Classroom atmosphere: songs and music are used to provide a pleasant classroom atmosphere, (2) Language input: songs and music are used to provide language rhythm exposure, (3) Cultural input: songs and music (especially pop music) provide an introduction to the culture, (4) Text: songs are used as learning texts, as are poems, short stories, and novels, (5) Supplement: songs are used as a complement to textbooks, and (6) Teaching and Student interest: songs can be used to teach conversation, vocabulary, grammatical structure, pronunciation, pattern training, and memory consolidation. Paul \& Chan (2010) add songs to make it easier for children to remember words and patterns and natural pieces of language (chunks of language). Based on the explanation above, it is clear that the song has various benefits to teach language in a more pleasant way that can make it easier for students to remember words, language patterns, and natural pieces of language, and can involve their feelings more deeply in learning. There are several types of songs that can be used for different teaching purposes, namely songs, poems, and verses that are sung in short (Brewster et al., 1992). Dzanic\&Pejic (2020) composed several types of songs, such as children's poetry, contemporary pop music, and songs specifically written to teach English.

Referring to the research results of Ratminingsih (2010) proves that song is one of the effective techniques to improve English students' listening skills at elementary school, the material and syntax of song-based learning can improve the English language competence of elementary students (Ratminingsih, 2010: Budasi, Ramendra, \& Suputra, 2013). Scripted song is songs that has been developed in which to maximize the integrated language learning and holistic language learning by involving language competence, for instance the cognitive domain (linguistic aspects), the psychomotor domain (written and oral communication), and the affective domain (culture value and character building). In addition, scripted songs aim to suit the need to teach the themes required in the local content curriculum. In this study, the songs teaching technique in form of Scripted Songs will be used to treat the students' English competence.

Eventually, this research aims to improve competence in communicating in a limited oral form to accompany action (language accompanying action) in the school context by emphasizing the listening and speaking aspects and providing an overview of whether the audio media based on the scripted song can increase the students' learning motivation in learning English at fifth-grade elementary school which is shown from their learning outcomes after being given action.

\section{METHOD}

The research design of the empirical test on the effectiveness of using audio media based on scripted song is before and after treatment (Sugiyono, 2010). The research location was SDN No.205 / IV Jambi, which is placed in the city border. Students who attend in this school are from the lower middle class who only learn English at school. In this research, fifth grade students of SDN 205/IV Jambi were selected as the population. There are 3 (three) classes. The 
sample was taken randomly involved 25 of the fifth grade students. Data collection techniques are through tests by giving 20 questions related to learning material with the topic "Time" which is taught as many as 2 sessions, it is $4 \times 35$ minute. the first the students are given the pretest to determine the initial ability of students, and then the material given in learning process by using audio media based on scripted song which is contains about the number and the time. The students were asked to listen the song and then repeat by singing together. In the last session, session 3 , students were given a final test (post-test) in the form of a test of learning outcomes by taking up the themes that had been taught and continued with the distribution of questionnaires about learning motivation to measure students' motivation in learning English by using audio media based on the scripted song.

The results of the study were analyzed descriptively. The nominal calculation results in the form of average scores that calculated using SPSS 17 are described quantitatively, namely the results of the initial test and the final test of students' English learning outcomes in the form of scores obtained before being given an action and after being given an action. The average score of students in English competence before being given an audio media based on scripted song is compared to after being given learning by using media based on scripted song.

Additional data from the results of the motivation questionnaire were also analyzed quantitatively to see how students' motivation towards learning with the implementation of an audio song-based media creation. Furthermore, the results of the analysis are described qualitatively to determine the effectiveness of the learning media used. Thus, the research question will be answered, namely whether the use of song-based audio media is effective in improving learning outcomes and student motivation to learn English in grade 5 at elementary school.

\section{RESULT and DISCUSSION}

Before the action (treatment) given, the competencies of fifth-grade students of SDN No.205 / IV Jambi City was taken from the semester one summative test scores when they sit in fifth grade. It is done determine the students ability in English before learn by using audio media based on the scripted song. The result of pre-test is as follow.

Table 1. Students' final test results before the treatment

\begin{tabular}{ccc}
\hline Score & Total Students & Criteria \\
\hline $8.6-10$ & 3 & Very Good \\
$7.1-8.5$ & 4 & Good \\
$5.6-7.0$ & 14 & Fair \\
$4.0-5.5$ & 2 & Lack \\
$0-3.9$ & 2 & Very Lack \\
\hline Total Students & 25 & \\
Total Score & 167.3 & Fair \\
Average & $\mathbf{6 . 6 9}$ & \\
\hline
\end{tabular}

Based on the table above it is known that there are 3 (three) students get very good criteria, 4 (four) students get good criteria, 14 (fourteen) students get fair criteria, 2 (two) students lack and 2 (two) students get very lack criteria. Overall, the students' average English language skills are in the fair criteria, which is 6.69.

After two learning sessions through the using of media based on the scripted song, the final test (post-test) was done. It is done to determine the students' English ability. The final test results are as in Table 2. 
Table 2. Students' final test results after the treatment

\begin{tabular}{ccc}
\hline Score & Total Students & Criteria \\
\hline $8.6-10$ & 8 & Very Good \\
$7.1-8.5$ & 13 & Good \\
$5.6-7.0$ & 4 & Fair \\
$4.0-5.5$ & 0 & Lack \\
$0-3.9$ & 0 & Very Lack \\
\hline Total Students & 25 & \\
Total Score & 208 & Good \\
Average & $\mathbf{8 . 3 2}$ & \\
\hline
\end{tabular}

Table 2 shows that given an action containing audio media containing a CD containing the scripted songs, student scores increased on the achievement of the average score of 8.32 with the category "Good". The language that supports it is audio media that contains scripted songs that effectively help improve students' English skills, especially in listening and speaking. What is meant by children's learners are those who learn English as a foreign language or second language in the first six or seven years of learning in formal schools and are usually taught in elementary schools. In terms of age, the average age between 5 to 12 years. Furthermore, Harmer (2007) suggests that the characteristics of children when learning is that they not only focus on what is taught but also learn many things at the same time, such as taking information from the surroundings. Seeing, listening, and touching are as important as the teacher's explanation in the process of understanding. Abstraction of grammatical rules is less effective when taught to children. Children usually respond well to activities that focus on their lives and experiences. However, children's attention that is the willingness to keep paying attention to an activity is usually short. One of the important characteristics of children is their ability to be competent speakers of a new language if the adequate facilities are provided and if they get the adequate language exposure.

Based on the results of the study there are interesting things: 2 students get a score below 4, which is classified as very lack and 2 students get a score between 4.0-5.5 which is classified as lack before being given an action. However, they can improve their English skills, this can be seen from the results of student tests after being given treatment. There are no students who are in the criteria of the value of "less" and "very less". This proves that students are helped improve learning outcomes through activities that interest them, namely through audio media. This confirms that the audio media that contains creative songs in the form of learning CDs effectively improves student learning outcomes. The results of this study are accordance with the previous research (Cuestas Cifuentes, 2006; Hidayanti, 2011; Jadal, 2011; Kömür, Saraç, \& Eker, 2005; Ratminingsih, 2010; Ratminingsih et al., 2013; Sevik, 2011). It states that the use of songs in learning constitutes Effective learning strategies are not only to improve their English learning outcomes specifically on the linguistic component, such as vocabulary but also on language skills namely listening and speaking. The results of this study are also in line with Griffee (1992) that songs can create a pleasant learning atmosphere so that it can provide fun not only for students who are able, but also who are less able, which have an impact on improving their learning outcomes. Besides, songs can provide language input that teaches conversation, vocabulary, grammatical structure, pronunciation, pattern training, and memory consolidation. Thus, all components of language and language skills can be integrated through songs.

The finding of the learning outcomes achieved by students also prove that the media can create meaningful contexts in learning English in various formats, such as print, audio, and visual, which in this study utilize audio formats that can be played with a CD player or computer (Yassaei, 2012). The linguistic context that is built through the scripted songs is stand proven effective in increasing the students' interest, motivation, and involvement in learning so that it affects improving learning outcomes. Thus, the results of the study support Hamalik (in Arsyad, 2011) who emphasizes the use of instructional media in teaching and learning processes that can arouse new desires and interests, arouse motivation and stimulation of learning activities 
and even bring psychological influence on students. Especially for young learners, who are still in the operational concrete development phase, for them, the physical world is being the focus of learning, which is in this research is attempted by the use of audio objects into learning, as an effort to vary the learning. This is consistent with the opinion of Scott \& Ytreberg (1990) and Shin (2006) that to increase the attention and involvement of students in learning, the main strategy is through the use of various supporting tools or learning media.

Also, based on the results of the questionnaire distributed to students, it is known that the using of audio media based on scripted song is effective for learning English in class at elementary school. It is evidenced from 16 students (100\%) expressed their opinion that they strongly agree with the use of songs in learning, because the song makes lessons interesting, fun, so they are motivated and encouraged they actively participate and stimulate their curiosity about what the teacher seriously means. This finding is consistent with the opinion of Sabay (2006) that motivation plays an important role for learning success. Their motivation in learning can be improved through the using of appropriate media, such as through the audio media of songs. Besides, they also stressed that learning through the audio media that containing songs make the students easy to understand the subject matter. Definetely, the lesson becomes more useful and also improve the student;s ability in English. It is accordance with the reserach conducted by Ratminingsih (2010) and Ratminingsih \& Burdasil (2012). It found that student's motivation in learning English can be increases with the use of scripted songs.

Meanwhile, Paul (2003) explain that songs add a whole dimension to children's classes, and make it easier for the children to remember words and patterns and natural chunks of language. Songs can add feeling and rhythm to language practice. It help the children to remember things more easily, and draw children more deeply into a lesson.

\section{CONCLUSIONS and SUGGESTION}

Audio media is one kind of media that is necessary used by English teachers at elementary schools in Jambi in particular or Indonesia in general. It gives variation of language exposure to EFL learners. One of the audio media used is based on the scripted song. Based on the analysis of the empirical test through the before and after treatment design, the using of audio media based on scripted song has proven to be effective in improving English learning outcomes of fifth-grade elementary school students, as evidenced by an increase in learning outcomes from 6.69 (enough) before the action to 8.32 (good) after the action. The students have a positive perception of the use of creative music-based audio media in learning, as evidenced by the results of the questionnaire that all students (100\%) strongly agree with the use of song-based audio media that can increase their learning motivation because through the use of songs, they stated that learning became more fun, interesting, so it was easier to understand the lesson.

It can be concluded that the using of audio media which consisted of scripted songs has provided contextual input of language skills especially in speaking and listening and language components (vocabulary and pronunciation) to students which could be proved to improve students' English achievement and their motivation to study English. Moreover, elementary school students will be motivated to learn English so they can improve their learning outcomes when they learn in a fun way. One of the ways to create a pleasant atmosphere is by using audio media based on scripted song.

This, the things that can be suggested based on the results of this research are (1) With the provision of audio media based on the scripted song the English teachers are expected to vary their learning using innovative media, such as the learning that contain of the scripted songs, which can increase the students' oral communication competence that integrates all components of language namely vocabulary, grammar, and pronunciation, motivation and student participation in learning, and (2) Because the audio media that containing the scripted songs has been proven to improve student learning outcomes, English teachers at elementary schools are advised to maximize the use of instructional media to present fun and interesting learning, so the purpose of English learning at elementary school will be achieved, it is student 
can practice the oral communication competence that integrates all components of language namely vocabulary, grammar, and pronunciation

\section{REFERENCES}

Ali E. \&Ece Z. T. (2019). Primary School Second Grade English Language Teaching Program: Insiders' Views on Its Strengths and Weaknesses. Elementary Education Online, 18 (4), 1467-1479.

Arsyad, A. (2011). Media of Learning. Jakarta: PT Raja Grafindo Persada. (Originally in Indonesian)

Bayu, G. W., \& Wahyuni, L. G. E. (2019). The Effectiveness of the Implementation of Enjoyable Learning Strategies assisted by Audio Visual Media on Early English Learning Outcomes of Elementary School Students. Elementary School Scientific Journal, 3(3), 341-348. (Originally in Indonesian)

Brewster, J., Ellis, G., \& Girard, D. (1992). The primary English teacher's guide. London: Penguin English.

Brown, H. D. (1994). Teaching by Principles: An Interactive Approach to Language Pedagogy. New Jersey: Prentice Hall Regents.

Budasi, I. G., Ramendra, D. P., \& Suputra, P. E. D. (2013). Development of English Language Audio Learning Media Theme-Based Special Songs (Scripted Songs). Research's Report. (Originally in Indonesian)

Chitravelu, N., Sithamparam, S., \& Teh, S. C. (2005). ELT Methodology: Principles and practice. Oxford: Fajar.

Csabay, N. (2006). Using Comic Strips in Language Classes. In English Teaching Forum. Vol. 44, 24-26.

Cuestas Cifuentes, M. (2006). Songs in the English class: A strategy to encourage tenth graders' oral production. Profile Issues in Teachers Professional Development, 7, 47-58.

Dimyati, M. (2006). Teaching and Learning. Jakarta: Rineka Cipta. (Originally in Indonesian)

Dwihartanti, M., \& Gafur, A. (2015). Development of Multimedia Learning English for Class IV at Elementary Schools to Improve Learning Outcomes. EFFICIENCY-Administrative Studies, 13(1). (Originally in Indonesian)

Gagne, R. M., \& Briggs, L. J. (1974). Principles of instructional design. Holt, Rinehart \& Winston.

Griffee, D. T. (1992). Songs in action. Prentice Hall.

Harmer, J. (1983). The practice of English language teaching. ERIC.

Harmer, Jeremy. (2007a). How to Teach English. Essex: Pearson Education Limited.

I Putu Mas Dewantara. (2020) Curriculum changes in Indonesia: Teacher constraints and students of prospective teachers' readiness in the implementation of thematic learning at low grade primary school. Elementary Education Online, 19.2, 1047-1060

Jadal, M. M. (2011). A study of effectiveness of the audio-visual- aids in teaching and learning of English at primary level in ZP Primary Schools of Solapur District. Indian Streams Research Journal, 1(7), 121.

Kömür, Ş., Saraç, G., \& Şeker, H. (2005). Teaching English through Songs (Practice in Muğla/Turkey). Sosyal Bilimler Enstitüsü Dergisi (ILKE), 15, 120.

Krashen, S. (2002). Second language acquisition and second language learning (1st Internet ed). Retrieved January, 11, 2006.

Mona K. I, Lucia B. \& Liudmila P. V. (2020). Improving English as a foreign language proficiency in elementary schools: Exploring students' and parents' perceptions. Elementary Education Online, $19(1), 31-41$.

Murphey, T. (1992). Music and Song. Oxford: University Press.

N. D. Džanić\&A. Pejić (2016) The effect of using songs on young learners and their motivation for learning English. An Interdisciplinary Journal, Vol 1, Issue 2, 40-54

Paul, D., \& Chan, M. (2010). Teaching English to children in Asia. Pearson: Longman Asia.

Paul, David. (2003). Teaching English to Children in Asia. Hong Kong: Pearson Education Asia Ltd.

Ramendra, D. P., \& Ratminingsih, N. M. (2006). Study of the use of learning aids (Audio Visual Aids) in the teaching and learning process of English subjects in elementary schools in the City of Singaraja: Efforts to actualize competency-based curriculum. Research' Report. Singaraja: Universitas Pendidikan Ganesha. (Originally in Indonesian)

Ramendra, D. P., \& Ratminingsih, N. M. (2007). Utilization of Audio-Visual Aids (AVA) in the teaching and learning process of English subjects in elementary schools. Jurnal Penelitian Dan Pengembangan Pendidikan, 1(2), 78-95. (Originally in Indonesian)

Ratminingsih, N. M. (2010). Effect of learning techniques and personality types on English listening skills: Experimental studies on Undiskha Singaraja LAB Elementary School students. Doctoral Disertation. (Originally in Indonesian) 
Ratminingsih, N. M., \& Budasi, I. G. (2012). Training on the use of special creation songs (scripted songs) in theme-based English learning at elementary schools in Sukasada District, Buleleng Regency. Research's Report of P2M. Universitas Pendidikan Ganesha.

Ratminingsih, N. M., \& Budasi, I. G. (2014). Development of audio-based learning media for English-based song creation in fifth grade elementary school. Research's Report. Universitas Pendidikan Ganesha Singaraja.

Richards, J. C., and Rodgers T. S. (2001). Approaches and Methods in Language Teaching. Cambridge: Cambridge University Press.

Sanz, C. (2005). Mind and context in adult second language acquisition: Methods, theory, and practice. Georgetown: University Press.

Schoepp, K. (2001). Reasons for using songs in the ESL/EFL classroom. The Internet TESL Journal, 7(2), $1-4$.

Scott, W. A., \& Ytreberg, L. H. (1990). Teaching English to children. London: Longman.

Sevik, M. (2011). Teacher views about using songs in teaching English to young learners. Educational Research and Reviews, 6(21), 1027.

Shin, J. K. (2006). Ten Helpful Ideas for Teaching English to Young Learners. In English Teaching Forum, Vol. 44, 2.

Shtakser, Inna. (2012). "Using Music and Songs in the Foreign Language Classroom". [Online] Retrived on 18-January-2020, at URL http://www.laits.utexas.edu/hebrew/music/music.html

Yassaei, S. (2012). Using Original Video and Sound Effects to Teach English. English teaching forum Vol. $50,12-16$.

Widodo, A. T., \& Raharjo, T. J. (2012). The Effectiveness of Learning English with Flashcards Media to improve Student Learning Outcomes. Innovative Journal of Curriculum and Educational Technology, 1(2). 